\title{
Subsidies and distorted markets: Do telecom subsidies affect competition?
}

\author{
Eric P. Chiang ${ }^{a}$, Janice A. Hauge ${ }^{b}$, Mark A. Jamison ${ }^{c}$ \\ ${ }^{a}$ Department of Economics; Florida Atlantic University; Boca Raton, FL 33431, United States; \\ E-mail: chiang@fau.edu \\ ${ }^{\mathrm{b}}$ Department of Economics; University of North Texas; Denton, TX 76203, United States; \\ E-mail: jhauge@unt.edu \\ ${ }^{\mathrm{c}}$ Public Utility Research Center, University of Florida, Gainesville, FL 32611, United States; \\ E-mail: mark.jamison@cba.ufl.edu
}

\begin{abstract}
There is general concern that producer subsidies distort competition. We examine a telecommunications subsidy system that transfers money from low cost regions to high cost regions of the U.S. Even though the system is designed to be competitively neutral, we find evidence that the system, combined with carrier of last resort policies, promotes cream skimming by entrants in low cost areas and deters entry in high cost areas, where incumbents are more likely than entrants to receive subsidies. We are unable to rule out the possibility that state regulatory policies favor incumbents in states that are net beneficiaries of the subsidy system.
\end{abstract}

JEL classification: L52, L96, O11

Key words: Subsidies, Universal Service Fund, Telecommunications, Regulation 


\section{Introduction}

Oftentimes governments subsidize production of products or services. National governments regularly provide financial support for agricultural production and transportation industries. Local governments in the United States frequently provide special tax breaks or other financial considerations to help support a local failing business or to attract a new business to an area. Many countries and many states in the United States are establishing subsidies and incentive programs for what are considered environmentally friendly technologies, such as solar energy. However, such government subsidies can distort markets and lower welfare. In cases where markets are competitive, governments may have an incentive to try to limit distortions by making such subsidy programs competitively neutral using additional policy tools and regulations.

In this paper we consider the impact of a particular subsidy program to study its effects on competition in the sector. We focus specifically on the telecommunications industry's Universal Service Fund (USF) in the United States. This is a particularly interesting situation for several reasons. First, industry regulators transformed the program in the 1990s from one designed specifically to subsidize particular local telephone monopolies to one that would be competitively neutral. Second, the fund more than doubled in size from 1999 to 2005 - from $\$ 1.7$ billion to $\$ 3.9$ billion $^{1}$ - raising the possibility that any market distortions caused by the subsidy may have grown as well. Third, there is interest among industry regulators and some interest groups in expanding high cost support to include broadband services, so any distortions could be extended into other markets. ${ }^{2}$ Lastly, there is concern among some state

\footnotetext{
${ }^{1}$ Figures provided by the Federal Communications Commission (http://www.fcc.gov).

${ }^{2}$ For example, the Federal-State Joint Board on Universal Service - which is a board that includes both federal and state regulators - has issued a public notice stating that support mechanisms in the future should include broadband.
} 
telecommunications regulators that the subsidy program unnecessarily and heavily taxes some states (and not others) to provide these subsidies.

Using county level telecommunications and demographic data from 1999 through 2002, we consider the high cost support subsidy within the USF program. We find that the high cost support subsidy has effects that run counter to the intended purposes of the fund. Specifically, we find that despite efforts to create a competitively neutral telecommunications support mechanism, the scheme interacts with another regulatory mechanism, the carrier of last resort policy, to distort competition. ${ }^{3}$ This occurs because the carrier of last resort policy requires incumbents to serve all customers in broad geographic areas. Entrants, on the other hand, may choose to serve any subset of customers. Ultimately entrants choose to operate in only the most profitable geographic areas. ${ }^{4}$ Thus, the carrier of last resort policy opens the door for cream skimming by entrants, and the high cost support mechanism exacerbates the problem by requiring incumbents and entrants to pay a portion of their revenues into the high cost fund, which is then used to subsidize telecommunications providers in high cost areas. We find that the effects of the policies together are not competitively neutral among incumbents and entrants.

The paper proceeds as follows. Section 2 provides background information and indicates how our research contributes to the existing literature addressing universal service subsidies. Section 3 presents our hypotheses and theoretical model of the effect of high cost support on telecommunications competition. Section 4 presents the data and empirical methodology. The

See Federal-State Joint Board (2007). The Benton Foundation Universal Service Project has also advocated extending the existing USF to broadband. See Taylor (2007).

${ }^{3}$ Some states have begun lifting carrier of last resort obligations on incumbent local exchange carriers.

${ }^{4}$ The term incumbent refers to the carrier that prior to the Telecommunications Act of 1996 provided local telephone service in an area. An entrant is a carrier that provides some or all of the local telephone service in an area that was not operating prior to the Act. 
results and policy discussion are presented in Section 5, and Section 6 concludes the paper.

\section{Universal service and high cost support}

The stated purposes of the U.S. Communications Act of 1934 included "regulating interstate and foreign commerce in communication by wire and radio so as to make available, so far as possible, to all the people of the United States,..., a rapid, efficient, nationwide, and worldwide wire and radio communication service with adequate facilities at reasonable charges." ${ }^{, 5}$ This goal is now commonly referred to as universal service, but subsidies for universal service are a much more recent invention. Indeed the Federal Communications Commission (FCC) did not adopt a policy of extensive subsidies for rural, high cost telecommunications companies until the late 1960s and the 1970 s - by which time nearly all households had telephone service. ${ }^{6}$

The rural telephone subsidy policy that the FCC embraced and extended and that had been administered by the AT\&T monopoly came under pressure in 1984, when a settlement between AT\&T and the U.S. Department of Justice resulted in AT\&T being divided into regional "Baby-Bells" and one long distance company. The FCC's response was to create a universal service fund to replace a portion of the implicit subsidy system that had been achieved through the regulation of the AT\&T monopoly. The new fund assessed competitive interstate long distance carriers to support local telephone monopolies that were required to maintain low prices

\footnotetext{
${ }^{5}$ This excerpt from the Communications Act of 1934 was obtained from the Federal Communications Commission (http://www.fcc.gov/Reports/1934new.pdf), accessed July 3, 2007.

${ }^{6}$ For detailed information on the establishment and progression of the universal service fund, see Gabel (1967), Mueller (1993), and Jamison (2002).
} 
in the name of universal service. ${ }^{7}$ The fund allowed special considerations for small companies serving in high cost areas, and helped to provide price discounts to low-income consumers.

Then in 1996, the Telecommunications Act opened competition in local markets. This meant that assessing competitive interstate long distance carriers to support incumbent local telephone companies (no longer monopolies) could distort market competition. However, the Act sought to preserve the subsidy flows and extended the dissemination of funds collected to include schools, libraries, and rural health care providers. To address each of these interests the FCC, in consultation with the Federal-State Joint Board on Universal Service, created a single federal Universal Service Fund (USF) composed of four programs: 1) high cost support; 2) Lifeline and Linkup; 3) schools and libraries; and 4) rural health. The focus of our research is high cost support.

The Telecommunications Act of 1996 mandated that incumbents and entrants contribute to the USF on an equitable and non-discriminatory basis, and industry regulators believed that providing USF money to all eligible telecommunications carriers operating in high cost areas could promote efficient competition. By treating incumbents and entrants the same with respect to the USF, the subsidy system should not distort competition. Still, the fund was designed so that while incumbents automatically qualified for high cost support, entrants were required to apply and demonstrate eligibility. ${ }^{8}$ During the period of our study, few entrants qualified for high cost support.

The USF is now a massive national program under the jurisdiction of the FCC. It disbursed $\$ 6.9$ billion in $2005, \$ 3.9$ billion of which was used to support companies operating in

\footnotetext{
${ }^{7}$ Intrastate long distance revenue also helped to pay for local exchange networks, but intrastate long distance did not contribute to the federal universal service programs.

${ }^{8}$ An entrant must first be designated as a competitive eligible telecommunications carrier before qualifying for high cost support.
} 
high cost service areas. ${ }^{9}$ The high cost support proportion of total USF support has grown in recent years, from $49 \%$ in 1999 to $57 \%$ in 2005 .

As the size of the program has grown, the USF has been increasingly criticized (see Hazlett, 2006, for an extensive critique). In recent years one issue of contention is that the volume of contributions to the USF and receipts from the USF varies across states, resulting in each state having either a net deficit or net surplus of USF contributions. States with telecommunications companies that contribute significantly to the fund but collect little from it are concerned that such revenue outflows constitute inefficient subsidies and hamper telecommunications development within their states. Some of these states advocate reducing the size of the federal program and promoting state-administered USF programs where fewer contributions would be sent out of state (Clark, 2005). Naturally, states that are net recipients of USF funding are against such proposals.

Table 1 shows the overall net USF contributions ranked across the 50 U.S. states and the District of Columbia. ${ }^{10}$ States with high net contributions to the USF, such as California, New York, Florida, and New Jersey, have voiced concern that they contribute much more to the USF than they receive from it, allowing states such as Alaska, Kansas, Arkansas, and Mississippi to receive significant net receipts from the USF. Formally, eligibility for high cost support is determined by the size of the incumbent telephone company serving the area and the degree to which the average cost of a local loop in the area is above the national average loop cost; smaller companies qualify for larger subsidies per line than do larger companies and companies with

\footnotetext{
${ }^{9}$ The remainder was disbursed for telecommunications assistance to low-income households, schools and libraries, and rural health centers.

${ }^{10}$ Table 1 uses 2004 contribution data.
} 
higher costs qualify for greater subsidies than do companies with lower costs. ${ }^{11}$ While states with large landmass, low population density, and challenging terrain tend to have relatively more high cost areas, these characteristics do not necessarily predict the overall level of USF net contributions for the state. Of further interest is the large difference between net contributor states and net recipient states when comparing the average net contribution by local loop, as shown in Figure 1. In 2004, net contributor states contributed at most \$20.56 per local loop (on average), while net recipient states received as much as $\$ 182.41$ dollars per local loop (on average). Clearly population density, as reflected by the number of local loops, is a critical indicator of net contributions.

[Insert Table 1 here.]

[Insert Figure 1 here.]

Literature addressing the USF generally has been critical of the welfare benefit of the fund to society. Wolak (1996) and Barros et al. (1999) show that wireline telecommunications penetration rates in the U.S., even in many rural areas, was approaching $100 \%$ when their articles were written; further, they cite evidence that few residents would disconnect service as a result of moderately rising prices. Garbacz and Thompson $(2002,2003)$ support these conclusions, showing demand for telecommunications services to be highly price inelastic. These studies indicate that the majority of the population has access to telecommunications services and chooses to subscribe to such services. These studies, coupled with research that has shown that nearly all households had telephone service before extensive subsidies were put in place (see, for

\footnotetext{
${ }^{11}$ Incumbent size is measured by the number of local loops (where a loop is essentially a local telephone line) served by the incumbent in the study area. The USF covers a higher percentage of local loop costs for study areas with fewer than 200,000 incumbent local loops than for study areas with more than 200,000 incumbent local loops.
} 
example, Mueller 1993 and Jamison 2002), indicate that primary justification for the USF (to ensure affordable telecommunications services for the entire population) is questionable.

Specifically addressing high cost support, Rosston and Wimmer (2000) argue that subsidies for high cost areas are inherently discriminatory. High cost areas (in terms of telecommunications provision) can include wealthy estates and remote vacation or secondary homes, while low cost areas are generally more urban and therefore may have a greater number of low-income households. In such cases, the high cost fund subsidizes the wealthy rather than low-income households who arguably are in greater need of assistance. Rosston and Wimmer argue that reducing high cost support would have no significant effect on universal service, while higher taxes needed to fund the program create costly distortions. Similarly, Cremer et al. (2001) and Chiang and Hada (2007) show that unbalanced rate structures whereby telecommunications prices do not closely reflect their costs cause a costly redistribution of welfare from one segment of the population to another. Eriksson et al. (1998) compare the effectiveness of untargeted subsidies such as the high cost fund and more targeted subsidies such as the Lifeline and Linkup (low-income) programs, and find that the latter are significantly more effective in increasing telephone subscriptions. Further, they show that the costs of funding any of these subsidies significantly offset the positive benefits that both untargeted and targeted subsidies aim to achieve. Lastly, Cremer et al. (2001) argues that high cost support is inefficient when the incumbent is not the most efficient operator. In this case, efficient competitors in effect support a less efficient incumbent.

One drawback of the existing literature is that most studies measure the effects of consumer well-being using the level of telephone penetration (i.e., the proportion of total households with access to telecommunications service, or the number of access lines). Yet, as 
Hazlett (2006) shows, while almost all U.S. households have access to a wireline provider, as of 2006 only approximately $89 \%$ actually paid to subscribe to wireline service. Additionally, the availability of wireless and Internet-based telephony reached over 95\% of U.S. households. Thus, the use of wireline penetration rate data seems no longer an effective means of measuring consumer well-being.

We study how states' net outflows of USF high cost support contributions affect competition. Based on the current national approach to administering the high cost support fund, we estimate the effect of net contributions on competition in a state by analyzing entry data at the county, study area, and state levels for all U.S. states and the District of Columbia for the fouryear period from 1999 through $2002 .{ }^{12}$ To our knowledge, this research is the first to empirically analyze cross-state effects of high cost support net contributions on the overall level of competition within a state. This is an important issue for policymakers who argue that positive net contributions to the high cost support fund are deleterious to a state's development of efficient telecommunications. It is also important for policymakers considering using USF-like subsidies for broadband because the subsidies may distort the competition that has proven important to broadband development. For example, Aron and Burnstein (2003) found that competition between telecommunications companies and cable television companies is the most effective catalyst for increased broadband penetration. Gruber and Denni (2005) reached the same conclusion two years later. Our main hypotheses follow.

\footnotetext{
${ }^{12}$ A study area is an area defined by the FCC that represents the geographic area within a state that was traditionally served by a particular incumbent. Incumbents that operate in more than one state will have a distinct study area for each state in which they operate. In some instances an incumbent may have more than one study area in a state if, for example, the company merged with another company in the state. Study areas cannot overlap, though more than one study area can appear in a single county.
} 


\section{Hypotheses and theoretical motivation}

Consider an incumbent telecommunications provider that is a net contributor to the high cost fund. Assume the incumbent has both high cost and low cost regions within its study area. A low cost region is generally urban with high customer density and/or relatively easy terrain in which to locate telephone lines; however, lower costs also might result from the use of older telecommunications facilities. ${ }^{13} \mathrm{~A}$ high cost region is generally rural and sparsely populated, and/or has more challenging terrain. Consider that the incumbent, having carrier of last resort responsibilities, must serve any customer within its study area who requests service. Its rivals do not have to serve the entire study area.

Let $A_{L}$ represent the incumbent's average, per customer cost for providing service in the study area. ${ }^{14}$ Assume the incumbent's prices to its customers reflect the average cost of providing service in the study area. This practice is called rate averaging and is a traditional pricing practice of regulated utilities. ${ }^{15}$ Let $L_{L}$ represent an entrant's cost for serving a customer in the low cost region of the study area. Research indicates entrants typically serve such low cost regions rather than entering high cost regions (Hauge et al., 2008). Assume that all else equal, customers prefer lower prices to higher prices, so the market share that the entrant gains in the low cost region is greater the lower its prices are relative to the prices of the incumbent. In other words, assuming that prices reflect underlying costs, the entrant's market share in the low cost area is increasing in $A_{L}-L_{L}$.

\footnotetext{
${ }^{13}$ Small, rural telephone companies qualify for high cost support based on their accounting costs, so the amount of depreciation that has occurred for their facilities affects their average loop costs, which affect their high cost support. Larger companies qualify for high cost support based on the results of a computer-based cost model that estimates what the regulators believe it should cost for the company to serve the area.

${ }^{14}$ The cost of operating in an area is based on a forward-looking cost model of building and operating the network.

${ }^{15}$ Rate averaging is a sufficient condition for our first hypothesis, but it is not a necessary condition. The necessary condition is that the regulator establishes price limits in such a way that the incumbent must use revenues from the low cost area to cover costs in the high cost area.
} 
Now consider the effect of a high cost subsidy system that is funded by a fee assessed against all telecommunications providers (incumbents and entrants) based on a percentage of each firm's revenue. ${ }^{16}$ Let $\alpha$ represent the percent of revenue each provider must contribute to the high cost fund, where $1>\alpha>0$. The incumbent, in order to pay the fee and cover its costs, must charge a customer at least $\frac{A_{L}}{1-\alpha}$. The entrant must charge at least $\frac{L_{L}}{1-\alpha}$. The result is that the entrant's increase in market share is greater with the subsidy mechanism than without it because the difference between $\frac{A_{L}}{1-\alpha}$ and $\frac{L_{L}}{1-\alpha}$ is increasing in $\alpha$. As Zolnierek et al. (2001), Jamison (2004), and Roycroft (2005) show, the more profitable a market is for entrants, the greater the entry in the market.

Now consider a study area that is a net recipient of the high cost fund. The incumbent provider is entitled to receive high cost funds for its service within the study area. Qualifying entrants also are entitled to such funds for their service. However, during the period of our study, few entrants had qualified to receive high cost support. The discrepancy makes it possible for incumbents in net recipient study areas to obtain a cost advantage over entrants. Such a case would occur if the subsidy $\hat{\mathrm{S}}$, where $\hat{\mathrm{S}}>0$, allows $A_{L}-\hat{\mathrm{S}}<L_{H}$, where $L_{H}$ is the per line costs of

\footnotetext{
${ }^{16}$ Per the current USF arrangement, contributions are collected from all telecommunications carriers providing interstate service based on a fixed percentage of their total end-user long-distance revenues (currently 10.5\%). There is a universal service exception for de minimis (non-common carrier) telecommunications carriers whose estimated contributions would be less than $\$ 10,000$. All carriers that provide service in rural or urban high cost areas receive support. This includes entrants that are designated as a competitive eligible telecommunications carrier. A rural area is primarily defined as a study area in which less than 15 percent of access lines are in cities of more than 50,000 (http://www.fcc.gov). High cost areas are defined with respect to the five components of high cost services, and are based on costs greater than $135 \%$ of the national average cost per line ( $\$ 27.51$ in 2002). For defined high cost areas with fewer than 200,000 working loops, the carrier receives $\$ 1$ in subsidies for each $\$ 1$ of loop costs above 150 percent of the national average loop cost. For defined high cost areas with more than 200,000 working loops, the carrier receives subsidies between 10 percent and 75 percent of costs, depending on how much the cost is above the national average.
} 
the incumbent and entrant, respectively. This would lower entrants' profitability and in theory lead to less entry. This leads to our first hypothesis, namely:

Hypothesis 1: Competition as measured through entry will be lower in net recipient study areas relative to net contributor study areas.

We reject our first hypothesis if we find that: (1) net contributions to the subsidy fund are statistically significant and negatively correlated with entry or; (2) the effects of net contributions are not statistically different from zero. If we fail to reject Hypothesis 1, we cannot yet conclude that the fund itself distorts competition. We propose two possible reasons why positive net contributions to the high cost fund might be correlated with more entry: (1) The structure of the USF program may not fully compensate for carrier of last resort obligations in net contributor areas and barriers to competitor eligibility for subsidies in net receiver areas; or (2) A state's status as a net contributor or net recipient of subsidy funds might influence state regulatory policies that impact the decision-making processes and profitability of entrants.

Regulatory policies in states that are net receivers to high cost support may (through a variety of intentional or unintentional means) be less encouraging of entry than their counterparts in net contributor states. For example, regulatory policies in net receiver states may lead to interconnection arrangements, or leased facility arrangements, that are less favorable to entrants. Additionally, net contributor states may have less stringent requirements for entrants to become classified as providers eligible to receive high cost support for operating in high cost areas. To determine whether state regulatory policy impacts entry under the USF, we broaden our analysis 
to consider whether a state being a net recipient or net contributor affects entry in that state. This leads to our second hypothesis, namely:

Hypothesis 2: States that are net contributors to high cost support adopt regulatory policies that are more favorable to entry relative to the regulatory policies of states that are net recipients.

We reject our second hypothesis if we find that states' regulatory characteristics and policies are not significant determinants of entry. Additionally, we reject the hypothesis if a state's status of being a net contributor is significantly and negatively correlated with entry. If we fail to reject our first hypothesis (i.e., we find that entry is relatively lower in net recipient study areas), but do reject our second hypothesis (entry is not related to state regulatory characteristics), we can conclude that the high cost fund directly distorts competition.

\section{Data and empirical methodology}

\subsection{Dependent variable}

We use a dataset that includes all entrants in the U.S. telecommunications market by city over the four-year period from 1999 through 2002. In the absence of any market distortions, we expect greater customer demand, lower provider costs, and pro-entrant regulatory policies to result in greater entry into a market. Given our goal of estimating the effect of high cost support contributions on entry, our primary empirical models use the total number of providers per county (and per study area) as dependent variables. ${ }^{17}$ Provider data is from the annual CLEC

\footnotetext{
${ }^{17}$ Our initial research included using the number of access lines as a dependent variable to measure investment. These specifications resulted in poor models with insignificant results. We submit that this is due to the fact that
} 
Reports from New Paradigm Resources Group, Inc., and includes both planned and operational voice and data network services provided by entrants. We also include services supplied by municipal providers such as those used for the city's own operations (meter reading, municipal data network, supervisory control and data acquisition, and voice) and those provided to others (cable television, long distance telephone, Internet access, broadband, fiber leasing, and local telephone). Municipal provider data is from the American Public Power Association. Note that while our data includes the existence of entrants by city by year, because our demographic variables are at the county level, we aggregate our city level data to the county level and control for the number of cities per county and for the total population.

We also estimate the effect of entry by study area because receipt of high cost support (as well as contributions) is determined at the study area level. For study area estimates, we match the county level data to study areas. Using detailed incumbent maps from all 50 states and the District of Columbia, we map each county to the single largest study area within the county borders. ${ }^{18}$ For the majority of counties (approximately $81 \%$ ), a single study area dominated the county. For the remaining counties, the study area representing the county was selected by either having the greatest physical area in the county or by the number of loops the designated incumbent served within the county. The latter criterion was used to map most of the remaining counties (approximately 68\%). ${ }^{19}$ This gives us a total of 12,536 observations $(3,134$ observations

access lines are frequently leased by entrants; therefore it is possible to have entry of one or more entrants without any increase in access lines at all.

${ }^{18}$ Incumbent maps were obtained from each state for which a map was available. In six states, incumbent maps were not necessary since only one incumbent serves the entire state. In three other states, complete incumbent listings by county were obtained in lieu of maps. Maps were provided by the Telephone Association or the Public Service Commission from each state. Specific documentation of sources is available upon request.

${ }^{19}$ The first criterion was used in cases in which two or more study areas were served by large incumbents (e.g., SBC and Verizon). This is because it is not possible to determine the number of loops an incumbent serves within a county when it serves multiple counties in a state. 
per year for four years), and represents 99.8 percent of all counties in the U.S. In only 7 counties nationwide were we unable to map a county to a study area due to incomplete data.

\subsection{Explanatory variables}

Our explanatory variables can be divided into three categories: costs of operating and the competitive environment; demographic indicators of demand; and regulatory characteristics. We include in our model those factors that have been found to be relevant determinants of entry into local telecommunications markets by prior studies (for example by Greenstein and Mazzeo, 2006; Alexander and Feinberg, 2004; Roycroft, 2005; and Zolnierek et al., 2001). Of primary interest for our analysis are net contributions to the USF. These additional costs of operating are measured in two ways: aggregate net contributions by county and study area (Net Contributions) and net contributions per loop by county and study area (Net Contributions per Loop). ${ }^{20}$ These variables serve as the key explanatory variables in our regression analyses to estimate the effects of the USF on competitive entry. ${ }^{21}$

To represent the competitive environment we include indicators for incumbents. We do this using variables that control for the leading incumbent serving each county and study area. These variables are named for the respective incumbent; for example, for each state the percentage of telecommunications revenue that is attributed to Qwest in a particular year is included as a variable (Qwest) in all observations where Qwest has a presence in that state. Additionally, we account for incumbents' direct effects on rivals through unbundled network

\footnotetext{
${ }^{20}$ At the state level, a comparison of these variables in 2004 appears in Table 1 and Figure 1, respectively.

${ }^{21}$ While the FCC makes available data on receipts from the USF (and specifically on high cost support), contributions to the USF are not directly provided. However, contributions can be calculated by multiplying the appropriate contribution factor (fixed across all states) by the respective time period's revenues for each state. Contribution factors change each quarter; thus, contributions must be calculated on a quarterly basis, and then summed for the annual totals. Next, these contributions include funding for all four USF programs. In order to narrow the contributions to the high cost portion, all of the contributions are multiplied by the percentage of total contributions appropriated to high cost support. This varies from year to year, and ranges from $49 \%$ to $52 \%$. Receipts are then subtracted from contributions to calculate net contributions.
} 
elements (UNEs). Regulators required incumbents to provide UNEs to rivals during the period of our study. ${ }^{22}$ If an incumbent finds it more profitable to provide retail services than to provide unbundled network elements, we would expect the incumbent to try to limit entry. Thus, if incumbents are able to affect entry, we would expect a positive relationship between entrant presence in a market and the ratio of prices of UNEs and comparable retail services. To capture this effect, we include as a variable the incumbent's average price for UNEs per line divided by the comparable retail price per line (UNE Ratio). Following Jamison (2004) we expect this variable to capture the potentially conflicting effects of regulation on incumbent and entrant incentives; we cannot predict which effect dominates. We expect service provider costs generally to fall with the amount of urbanization or population density and choose to measure this in two ways. In the county level estimates we include population per square mile (Population per Square Mile) and annual payroll (Annual Payroll) as an indicator of market size. The latter data has the benefit of encompassing two effects indirectly, population and wealth associated with the area. In the study area level estimates, we incorporate total population (Population) and aggregate income (Income). Together these variables provide an estimate of market size that should reflect the competitive environment being studied. Lastly, we include the number of cellular telephone providers per county per year (Cellular Carriers) to account for the possible substitution effect that may decrease demand for wireline telephone service when more wireless providers are available.

\footnotetext{
${ }^{22}$ Leasing portions of an incumbent's network is called purchasing unbundled network elements. For example, an entrant could lease a local telephone line from the incumbent provider. The line would connect to the incumbent's building. It could then connect to the incumbent's switch or the entrant's switch, depending on how the entrant wishes to use the incumbent's facilities. Our variable is a state-wide average rate based on the loop, port and switching rates per month.
} 
With respect to our second category of variables, demographic indicators of demand, we use those variables that prior studies estimating demand have generally found to be significant. ${ }^{23}$ We expect demand to be positively related to household income, and measure this effect using the median annual household income within the county (Median Household Income). This corresponds to our inclusion of Income within the study area level estimates. We also include the percentage of the population that receives government assistance (Assistance) and anticipate this will be inversely related to demand. Finally, we include the median age of the population in the county and study area (Median Age). While we do not have a strong prediction on the effect of age on competitive entry, a study by Chiang and Hada (2007) showed that younger consumers tend to value choices in providers more than older consumers. If this is accurate, we would predict greater entry in counties with a lower median age. ${ }^{24}$

With respect to the final category of variables, the regulatory environment, we include three variables to estimate the effect of state regulatory conditions on competition. First, we include the binary variable Entrant Flexible Regulation (with the excluded category all other types of regulation) to distinguish between states that do and do not impose price floors on entrants. Because the imposition of price floors restricts the ability for entrants to compete on price, we expect states that do not impose such restrictions to attract greater entry, and therefore we expect a positive correlation between Entrant Flexible Regulation and the presence of entrants in a market. Second, we measure whether public service commissioners are appointed

\footnotetext{
${ }^{23}$ Because penetration rates for telecommunications services are high within the U.S., it is difficult to predict the factors that potential competitors would consider when deciding if there is enough demand to support their entry. For more detailed consideration, see Garbacz and Thompson (2002 and 2003) and Grzybowski (2005), or Alexander and Feinberg (2004) who provide a review of telecommunications entry literature.

${ }^{24} \mathrm{We}$ considered additional population characteristics such as race and ethnicity, language, and education, and other measures of population density such as urban classification, and various demographic indicators such as the employment growth rate and personal bankruptcy rate. These variables proved to be insignificant and did not affect results, and therefore were excluded from the model.
} 
rather than elected with the binary variable PSC Appointed. We do not have an a priori prediction on the possible effects of public service commissioners being appointed rather than elected. It is possible that elected commissioners are more responsive to immediate citizen concerns, but it is unclear whether this means that the commissioners might favor entrants, incumbents, or neither. ${ }^{25}$ Lastly, we include a variable that indicates whether a particular state has imposed restrictions on municipal telecommunications entry (Muniban). While municipal entry is a small subset of total entry, those states with regulations limiting such entry may have motivations for doing so that also discourage entry by non-municipal entrants.

Summary statistics for all variables are provided in Table 2 .

[Insert Table 2 here.]

\subsection{Empirical methodology}

Our fundamental empirical model is based on the theoretical model outlined in Section 3 above. We examine two dependent variables, the number of providers per county, and the number of providers per study area. Our primary interest is to determine whether net contributions to the USF affect entry; however, it is clear that similar factors affect both an entrant's decision to provide telecommunications services in a particular market and the net contributions that ultimately accrue to (or are received from) that market. Therefore, our data is likely to be characterized by endogeneity of the key regressor Net Contributions (and Net Contributions per Loop). The standard tests for endogenous variables support our concern. By the Wu-Hausman F-test we fail to reject the null hypothesis that the regressor Net Contributions is endogenous $(\mathrm{P}-$ value $=0.00137)$. The Durbin-Wu-Hausman chi-sq test has a similar result $(\mathrm{P}-$

\footnotetext{
${ }^{25}$ We generically refer to state regulatory agencies as public service commissions. Some states elect their commissioners. In other states they are appointed. The appointment processes vary across states, but the processes generally involve both the governor and the legislatures.
} 
value $=0.00136)$. To address this correlation, we employ a two-stage least squares estimation in which we use total number of loops as the instrumental variable for Net Contributions. ${ }^{26}$ The set of independent variables is as listed in Table 2, and models are specified for dependent variables Entrants per County and Entrants per Study Area both with and without identifying the primary incumbent provider. Additionally, in order to tie the results of the county level estimations to the state level policy analysis this paper addresses, we test simply for the significance of states being net contributors to the USF (Net Positive) versus being net recipients of the USF. We consider the variable Net Positive at all three levels of observation: county, study area, and state. The results of these estimations appear in Tables 3 and 4 and are discussed in the next section.

\section{Results}

We segmented our results to take into account both entrants per county and entrants per study area in order to capture any significant differences since our primary variable of interest (Net Contributions) is determined at the study area level. While we address the specifications separately it is important to note that the coefficients of both Net Contributions and Net Contributions per Loop are positively and statistically significant across all six specifications. Thus, our first hypothesis is supported in that we find net contributions to correspond with greater entry. However, as discussed earlier, this is insufficient for concluding that the high cost fund directly affects entry. Of interest, then, is to discern whether state regulatory policies influence the coefficients for the net contribution variables. Prior to addressing this question, we first consider the remaining explanatory variables within the county level specifications.

$$
\text { [Insert Table } 3 \text { here.] }
$$

\footnotetext{
${ }^{26}$ Loops is highly correlated with net contributions $(0.892)$, however is independent of the dependent variable(s) and uncorrelated with the error term.
} 
Across the county level specifications we find that the coefficients of variables controlling for the incumbent's share of total state revenue are generally insignificant indicating that entry is not greatly influenced by the leading incumbent in a market relative to small carriers (the excluded incumbent). It is beyond the scope of this paper to determine why various incumbents have different effects on entry; we expect it is related to corporate strategies (such as marketing practices, service quality, and how to respond to entry) and other firm-specific variables that are not captured in our model. Consistent with our expectations, we find that $U N E$ Ratio is positively and significantly correlated with entry. This finding suggests that incumbents that can earn higher revenue by leasing their unbundled network elements are less likely to act to limit entry, as the relative gains from serving retail customers are less important. The coefficients of the variable Cellular Carriers have the expected negative signs in the county level estimates however are statistically insignificant. Finally, we find Annual Payroll to be positively and significantly correlated with entry at the county level, and Population and Income to be positively and significantly correlated with entry in specification (6) at the study area level. The latter variable should indicate lower per customer costs, while Annual Payroll should indicate the market size; i.e., the wealth and ability to sustain multiple operators in an area. ${ }^{27}$

With respect to our second category of variables (indicators of demand), we find Median Household Income to be positively and significantly correlated with entry. Median Age is negatively correlated with entry, which supports the notion that younger consumers place higher value in advanced technologies and the availability of new and improved products that result from competition than older consumers. Additionally, the percentage of the population receiving

\footnotetext{
${ }^{27}$ We incorporate Annual Payroll in the Entrants per County specifications to capture the size of the local market. As the market size expands to the study area level, the correlation between Annual Payroll and Income becomes too high to include both variables. We therefore employ Population and Income which are independent and serve as an effective measure of market size.
} 
government assistance (Assistance) is positively and significantly correlated with entry. We expect that this variable reflects a higher level of urbanization where a greater number of lowerincome households may reside.

With respect to the final category of variables, the regulatory environment, we find that Entrant Flexible Regulation is associated with lower likelihood of the presence of entrants in a market. It is possible that this result, which is counter to our initial expectation, reflects a response by regulators to satisfy incumbents by incorporating other rules that might deter competitive entry in markets that are more attractive to entrants. We find that the appointment of public service commissioners is positively and significantly associated with entry in the county level estimates, although it is negatively associated with entry in specification (6) at the study area level. It is unclear why such difference may exist; we assert that the study area level estimates may not as accurately reflect the environment due to the manner in which the data are aggregated. Finally, the presence of restrictions on municipal entry is not significant at any level, except in our second model, which uses county level data and controls for incumbents, and our sixth model, which uses study area level data and controls for incumbents. The significant, negative coefficient in our second model may indicate that states that banned municipal entry also adopted policies that favored incumbents over entrants. The significant, positive coefficient in our sixth model may indicate that the entrants in small, high cost study areas are largely municipal providers. Hauge et al. (2008) find that municipal providers of telecommunications compete more with incumbents than with privately owned new entrants, which is consistent with our second model, and that municipal providers primarily enter markets in small, rural communities where privately owned entrants choose not to go, which is consistent with our sixth model. 
Focusing on the study area level results presented in Table 3, note that the same estimations were performed after aggregating the county level variables to the corresponding study area. While the majority of results are qualitatively similar to the county level specifications, coefficients for key variables are strengthened, including those for $\mathrm{Net}$ Contributions and UNE Ratio. The coefficients of variables controlling for incumbent's share of total state revenue all are insignificant. Similarly, the coefficients of Entrant Flexible Regulation are not significant in the study area estimates.

The results of the initial estimates as presented above provide us with the foundation for testing our first hypothesis. Namely, we find that certain cost, environment, demographic, and regulatory factors are relevant to entry decisions. Some of these factors differ by county (i.e., population); some differ by state (i.e., election of public utility commissioners); still others differ by study area (i.e., incumbent status). Our primary concern, however, is how Net Contributions affect the competitive environment. Therefore, we attempt to further clarify the effect of USF contributions on entry between net contributors and net recipients through the indicator variable Net Positive. Net Positive takes the value of 1 if the area (county, study area or state) is a net contributor to the high cost fund, and 0 otherwise. We compare the net change in providers from 1999 to 2000,2000 to 2001, and 2001 to 2002 by county, study area, and state, given the specified area's classification as being a net contributor (i.e., Net Positive $=1$ ) or a net recipient. The results of these estimates appear in Table 4.

[Insert Table 4 here.]

In these estimations, the coefficients of Net Positive are positive and significant, indicating greater entry with positive net contributions. This holds regardless of whether incumbents are included, and whether they are measured at the county, study area, or state levels. 
These results suggest that states may support regulatory policies that favor specific incumbents when the incumbents are net recipients of high cost support. This outcome is further reinforced at the study area and county level where policies are largely influenced by each respective state.

Given our results in Table 4, we accept our second hypothesis, namely, that states that are net contributors to high cost support adopt regulatory policies that encourage more competition relative to the regulatory policies of states that are net recipients. These findings do not rule out the possibility that the USF directly distorts entry; it is possible that there exists a complementary effect between the incentives inherent in USF subsidies and state regulatory policies aimed at preserving these subsidies that ultimately result in an outcome where subsidies deter entry in areas where entry otherwise might occur.

\section{Conclusion}

We examine whether subsidy mechanisms that are designed to be competitively neutral are truly neutral in their effects. We find that it is important to consider the subsidy policies in their contexts, namely, that a subsidy mechanism may interact with other policies and so distort competition. We also find that the subsidy mechanisms may provide incentives for policymakers whose jurisdictions benefit from the subsidies to adopt policies that protect the subsidized companies.

Focusing on a specific subsidy mechanism - the high cost fund in U.S.

telecommunications - we find that there are at least two potential negative effects on competition created by the high cost support. First, entrants are negatively affected by their contributions paid to the USF given that they qualify for the subsidy less frequently than do incumbents. The more 
significant issue, however, is whether the fund distorts competition. In other words, is efficient entry discouraged by the high cost system? We assert that this is the case. While contributions to the USF affect the profitability of all operators, it is the USF funding system that gives entrants a possible advantage over an incumbent when the incumbent is a net contributor. Because an incumbent is forced to serve both low cost and high cost regions in a study area and an entrant does not have such a requirement, the incumbent is less able to effectively compete in the low cost areas. Simultaneously, states with many high cost areas have less entry due simply to costs, and we find that being a net recipient of USF subsidies does not encourage entry. In fact, contrary to the intentions of policymakers, being a net recipient might discourage efficient competition when it is difficult for entrants to qualify for subsidies.

For future work, relevant questions remain. First, how might entrants respond if the USF were abolished altogether? In this case, we would be interested in the level of entry that would occur relative to the level of entry in net contributing states under the USF. Alternatively, how might entrants respond if a state-administered USF were implemented? We also might consider the role of specific incumbents on entry. This would require incorporating firm-specific data on pricing and costs. Despite these lingering questions, our key finding remains that increased entry is correlated with positive net USF contributions. This adds a new dimension to the ongoing debate on industry subsidies. 


\section{References}

Alexander, D., Feinberg, R., 2004. Entry in local telecommunication markets. Review of Industrial Organization 25, 107-127.

Aron, D. J., and Burnstein, D. E. 2003. Broadband adoption in the United States: An empirical analysis. Social Science Research Network, DOI: 10.2139/ssrn.386100.

Barros, P. P., Seabra, M. C., 1999. Universal service: Does competition help or hurt? Information Economics and Policy 11, 45-60.

Chiang, E. P., Hada, S., 2007. Telecommunications competition, rate-rebalancing, and consumer welfare in Nepal. Under review.

Clark, D., 2005. New telecom bill spurs industry split. Technology Daily, December 16.

Cremer, H., Gasmi, F., Grimaud, A., Laffont, J. J., 2001. Universal service: An economic perspective. Annals of Public and Cooperative Economics 72, 5-43.

Eriksson, R. C., Kaserman, D. L., Mayo, J. W., 1998. Targeted and untargeted subsidy schemes: Evidence from post divestiture efforts to promote universal service. Journal of Law and Economics 41, 477-502.

Federal-State Joint Board on Universal Service, 2007. Statement on long term, comprehensive high-cost universal service reform. Federal Communications Commission WC Docket No. 05-337 and CC Docket No. 96-45, Released September 6, 2007.

Gabel, R., 1967. Development of separations principles in the telephone industry. East Lansing, Michigan: Michigan State University Institute of Public Utilities.

Garbacz, C., Thompson, H. G., 2003. Estimating telephone demand with state decennial census data from 1970 - 1990: Update with 2000 data. Journal of Regulatory Economics 24, 373378.

Garbacz, C., Thompson, H. G., 2002. Estimating telephone demand with state decennial census data from 1970 - 1990. Journal of Regulatory Economics 21, 317-329.

Greenstein, S. M., Mazzeo, M. J., 2006. The role of differentiation strategy in local telecommunication entry and market evolution: 1999 - 2002. Journal of Industrial Economics 54, 323-350.

Gruber, H., and Denni, M. 2005. The diffusion of broadband telecommunications: The role of competition. Social Science Research Network. http://ssrn.com/abstract=829504.

Grzybowski, L., 2005. Regulation of mobile telephony across the European Union: An empirical analysis. Journal of Regulatory Economics 28, 47-67. 
Hauge, Janice A., Mark A. Jamison, and Richard J. Gentry. 2008. "Bureaucrats as Entrepreneurs: Do Municipal Telecom Providers Hinder Private Entrepreneurs?" Information Economics and Policy, 20(1):89-102.

Hazlett, T. W., 2006. Universal service telephone subsidies: What does \$7 billion buy? Analysis Group Policy Paper.

Jamison, M.A., 2002. The role of costing as a ratemaking tool in an environment of dynamic change. In The Institutionalist Approach to Public Utilities Regulation, ed. Edythe Miller and Warren J. Samuels, 250-75. East Lansing: Michigan State University Press.

Jamison, M. A., 2004. Effects of prices for local network interconnection on market structure in the US. In Global Economy and Digital Society, Chapter 16, Elsevier Science.

Mueller, M., 1993. Universal service in telephone history: A reconstruction. Telecommunications Policy 17, 352-369.

Rosston, G. L., Wimmer, B. S., 2000. The 'state' of universal service. Information Economics and Policy 12, 261-283.

Roycroft, T. R., 2005. Empirical analysis of entry in the local exchange market: The case of Pacific Bell. Contemporary Economic Policy 23, 107-115.

Taylor, R. D. 2007. Time for change: Transforming funding for broadband universal service. Institute for Information Policy, Pennsylvania State University, Working Paper of the Benton Foundation Universal Service Project.

Wolak, F. A., 1996. Can universal service survive in a competitive telecommunications environment? Evidence from the United States Consumer Expenditure Survey. Information Economics and Policy 8, 163-203.

Zolnierek, J., Eisner, J., Burton, E., 2001. An empirical examination of entry patterns in local telephone markets. Journal of Regulatory Economics 19, 143-159. 
Table 1. Rank of net contributions into the Universal Service Fund, by state

\begin{tabular}{|c|c|c|c|c|c|}
\hline Rank & State & 2004 Net & 2003 Net & 2002 Net & 2001 Net \\
\hline 1 & California & $\$ 266,002$ & $\$ 245,677$ & $\$ 211,070$ & $\$ 161,039$ \\
\hline 2 & New York & $\$ 170,352$ & $\$ 155,401$ & $\$ 136,693$ & $\$ 110,964$ \\
\hline 3 & Florida & $\$ 142,908$ & $\$ 132,688$ & $\$ 104,909$ & $\$ 83,115$ \\
\hline 4 & New Jersey & $\$ 125,693$ & $\$ 117,060$ & $\$ 116,018$ & $\$ 99,130$ \\
\hline 5 & Pennsylvania & $\$ 87,788$ & $\$ 78,072$ & $\$ 73,295$ & $\$ 69,462$ \\
\hline 6 & Illinois & $\$ 83,183$ & $\$ 71,868$ & $\$ 75,951$ & $\$ 72,009$ \\
\hline 7 & Massachusetts & $\$ 80,355$ & $\$ 75,113$ & $\$ 73,991$ & $\$ 67,425$ \\
\hline 8 & Ohio & $\$ 77,174$ & $\$ 69,475$ & $\$ 62,861$ & $\$ 56,913$ \\
\hline 9 & Maryland & $\$ 73,800$ & $\$ 68,214$ & $\$ 61,806$ & $\$ 52,470$ \\
\hline 10 & Michigan & $\$ 50,130$ & $\$ 47,480$ & $\$ 38,452$ & $\$ 30,459$ \\
\hline 11 & Connecticut & $\$ 49,234$ & $\$ 45,855$ & $\$ 42,682$ & $\$ 38,238$ \\
\hline 12 & North Carolina & $\$ 22,976$ & $\$ 23,767$ & $\$ 23,228$ & $\$ 32,827$ \\
\hline 13 & Virginia & $\$ 22,394$ & $\$ 18,321$ & $\$ 17,179$ & $\$ 12,059$ \\
\hline 14 & D. Columbia & $\$ 16,900$ & $\$ 15,801$ & $\$ 15,322$ & $\$ 14,149$ \\
\hline 15 & Delaware & $\$ 12,233$ & $\$ 11,365$ & $\$ 10,875$ & $\$ 9,406$ \\
\hline 16 & Rhode Island & $\$ 12,052$ & $\$ 11,274$ & $\$ 11,232$ & $\$ 10,678$ \\
\hline 17 & Tennessee & $\$ 9,440$ & $\$ 7,628$ & $\$ 4,943$ & $\$ 5,991$ \\
\hline 18 & Indiana & $\$ 8,633$ & $\$ 6,144$ & $\$ 7,484$ & $\$ 4,052$ \\
\hline 19 & New Hampshire & $\$ 6,390$ & $\$ 5,651$ & $\$ 5,677$ & $\$ 6,222$ \\
\hline 20 & Nevada & $\$ 5,855$ & $\$ 1,569$ & $\$ 3,339$ & $\$ 658$ \\
\hline 21 & Utah & $\$ 2,440$ & $-\$ 586$ & $\$ 3,081$ & $\$ 4,954$ \\
\hline 22 & Hawaii & $\$ 1,953$ & $\$ 3,945$ & $\$ 3,554$ & $\$ 4,511$ \\
\hline 23 & Georgia & $-\$ 3,269$ & $-\$ 9,524$ & $-\$ 19,051$ & $-\$ 9,633$ \\
\hline 24 & Texas & $-\$ 9,538$ & $-\$ 5,860$ & $-\$ 20,889$ & $-\$ 27,264$ \\
\hline 25 & Arizona & $-\$ 13,096$ & $-\$ 7,102$ & $-\$ 4,941$ & $-\$ 391$ \\
\hline 26 & Washington & $-\$ 15,024$ & $-\$ 10,684$ & $-\$ 19,451$ & $-\$ 21,216$ \\
\hline 27 & Maine & $-\$ 15,404$ & $-\$ 15,942$ & $-\$ 16,438$ & $-\$ 16,952$ \\
\hline 28 & Colorado & $-\$ 21,074$ & $-\$ 17,253$ & $-\$ 9,898$ & $-\$ 11,982$ \\
\hline 29 & Vermont & $-\$ 22,752$ & $-\$ 19,900$ & $-\$ 17,960$ & $-\$ 15,709$ \\
\hline 30 & Missouri & $-\$ 24,019$ & $-\$ 30,386$ & $-\$ 33,291$ & $-\$ 37,460$ \\
\hline 31 & South Carolina & $-\$ 26,801$ & $-\$ 33,467$ & $-\$ 35,846$ & $-\$ 19,688$ \\
\hline 32 & Nebraska & $-\$ 27,278$ & $-\$ 25,885$ & $-\$ 15,198$ & $-\$ 11,202$ \\
\hline 33 & New Mexico & $-\$ 28,231$ & $-\$ 29,280$ & $-\$ 26,429$ & $-\$ 26,675$ \\
\hline 34 & Oregon & $-\$ 29,126$ & $-\$ 31,228$ & $-\$ 30,750$ & $-\$ 27,802$ \\
\hline 35 & Kentucky & $-\$ 30,018$ & $-\$ 21,432$ & $-\$ 20,843$ & $-\$ 3,015$ \\
\hline 36 & Idaho & $-\$ 37,183$ & $-\$ 36,187$ & $-\$ 34,624$ & $-\$ 30,612$ \\
\hline 37 & Minnesota & $-\$ 40,146$ & $-\$ 28,919$ & $-\$ 23,322$ & $-\$ 7,202$ \\
\hline 38 & Wisconsin & $-\$ 46,417$ & $-\$ 37,623$ & $-\$ 22,112$ & $-\$ 20,117$ \\
\hline 39 & West Virginia & $-\$ 46,900$ & $-\$ 58,322$ & $-\$ 63,568$ & $-\$ 57,682$ \\
\hline 40 & North Dakota & $-\$ 47,132$ & $-\$ 43,850$ & $-\$ 26,466$ & $-\$ 20,488$ \\
\hline 41 & Wyoming & $-\$ 48,060$ & $-\$ 41,090$ & $-\$ 35,366$ & $-\$ 30,196$ \\
\hline 42 & South Dakota & $-\$ 48,253$ & $-\$ 40,823$ & $-\$ 25,663$ & $-\$ 16,473$ \\
\hline 43 & Iowa & $-\$ 49,541$ & $-\$ 40,239$ & $-\$ 15,744$ & $-\$ 12,155$ \\
\hline 44 & Alabama & $-\$ 50,456$ & $-\$ 46,404$ & $-\$ 57,792$ & $-\$ 61,119$ \\
\hline 45 & Louisiana & $-\$ 57,706$ & $-\$ 47,250$ & $-\$ 48,967$ & $-\$ 46,735$ \\
\hline 46 & Montana & $-\$ 62,850$ & $-\$ 54,872$ & $-\$ 53,437$ & $-\$ 43,073$ \\
\hline 47 & Oklahoma & $-\$ 63,913$ & $-\$ 70,645$ & $-\$ 56,037$ & $-\$ 50,272$ \\
\hline 48 & Alaska & $-\$ 84,716$ & $-\$ 80,099$ & $-\$ 73,278$ & $-\$ 71,528$ \\
\hline 49 & Kansas & $-\$ 97,509$ & $-\$ 83,112$ & $-\$ 67,221$ & $-\$ 57,763$ \\
\hline 50 & Arkansas & $-\$ 107,380$ & $-\$ 86,135$ & $-\$ 69,254$ & $-\$ 57,959$ \\
\hline 51 & Mississippi & $-\$ 157,193$ & $-\$ 142,470$ & $-\$ 144,482$ & $-\$ 120,223$ \\
\hline
\end{tabular}

Note: Monetary figures represent thousands of U.S. Dollars 
Table 2 . Summary statistics, by county (1999 - 2002); 12,535 observations

\begin{tabular}{|c|c|c|c|c|}
\hline $\begin{array}{c}\text { Variable } \\
\end{array}$ & Mean & Std. Dev. & Min & Max \\
\hline Number of Entrants per County & 0.818 & 3.561 & 0 & 80.000 \\
\hline $\begin{array}{l}\text { Net Contributions } \\
\text { (in hundreds of thousands) }\end{array}$ & 13.900 & 35.700 & -91.200 & 188.000 \\
\hline $\begin{array}{l}\text { Net Contributions per Loop } \\
\text { (in thousands) }\end{array}$ & -0.099 & 0.253 & -7.373 & 0.277 \\
\hline Average Revenue per Line & 35.236 & 4.648 & 25.280 & 45.880 \\
\hline UNE Ratio & 16.053 & 4.325 & 7.014 & 28.295 \\
\hline $\begin{array}{l}\text { Alltel } \\
\text { (market share) }\end{array}$ & 0.029 & 0.084 & 0.000 & 0.366 \\
\hline $\begin{array}{l}\text { BellSouth } \\
\text { (market share) }\end{array}$ & 0.204 & 0.359 & 0.000 & 1.000 \\
\hline $\begin{array}{l}\text { SBC } \\
\text { (market share) }\end{array}$ & 0.195 & 0.336 & 0.000 & 1.000 \\
\hline $\begin{array}{l}\text { Sprint } \\
\text { (market share) }\end{array}$ & 0.041 & 0.085 & 0.000 & 0.685 \\
\hline $\begin{array}{l}\text { Qwest } \\
\text { (market share) }\end{array}$ & 0.204 & 0.374 & 0.000 & 1.000 \\
\hline $\begin{array}{l}\text { Verizon } \\
\text { (market share) }\end{array}$ & 0.186 & 0.309 & 0.000 & 1.000 \\
\hline $\begin{array}{l}\text { Small Carriers } \\
\text { (market share) }\end{array}$ & 0.141 & 0.320 & 0.000 & 1.000 \\
\hline Cellular Carriers & 10.042 & 3.152 & 4.000 & 18.000 \\
\hline $\begin{array}{l}\text { Population per Square Mile } \\
\text { (in thousands) }\end{array}$ & 0.216 & 1.430 & 0.001 & 52.419 \\
\hline $\begin{array}{l}\text { Population } \\
\text { (in thousands) }\end{array}$ & 89.777 & 292.741 & 0.067 & $9,519.338$ \\
\hline $\begin{array}{l}\text { Annual Payroll } \\
\text { (in hundreds of millions) }\end{array}$ & 12.001 & 56.734 & 0.001 & $1,640.00$ \\
\hline $\begin{array}{l}\text { Median Household Income } \\
\text { (in thousands) }\end{array}$ & 35.328 & 8.852 & 9.333 & 82.929 \\
\hline $\begin{array}{l}\text { Aggregate Income } \\
\text { (in hundreds of millions) }\end{array}$ & 19.10 & 66.400 & 15.860 & $1,940.00$ \\
\hline Median Age & 37.354 & 4.004 & 20.125 & 58.686 \\
\hline $\begin{array}{l}\text { Assistance } \\
\text { (percent of households) }\end{array}$ & 2.963 & 1.960 & 0.000 & 49.013 \\
\hline $\begin{array}{l}\text { Entrant Flexible Regulation } \\
(=1 \text { if Yes; } 0 \text { if No) }\end{array}$ & 0.508 & 0.500 & 0.000 & 1.000 \\
\hline $\begin{array}{l}\text { PSC Appointed } \\
(=1 \text { if Yes; } 0 \text { if No) }\end{array}$ & 0.695 & 0.461 & 0.000 & 1.000 \\
\hline $\begin{array}{l}\text { Muniban } \\
\text { (=1 if restrictions; } 0 \text { otherwise) }\end{array}$ & 0.050 & 0.217 & 0.000 & 1.000 \\
\hline
\end{tabular}


Table 3. Two-stage least squares estimates for entry per county and per study area

\begin{tabular}{|c|c|c|c|c|c|c|}
\hline $\begin{array}{l}\text { Regression Number } \\
\text { Dependant Variable }\end{array}$ & \multicolumn{3}{|c|}{ Entrants per County } & \multicolumn{3}{|c|}{ Entrants per Study Area } \\
\hline Net Contributions & $\begin{array}{l}0.006^{* * *} \\
(0.001)\end{array}$ & $\begin{array}{l}0.006^{* * *} \\
(0.001)\end{array}$ & & $\begin{array}{l}1.380^{* * *} \\
(0.002)\end{array}$ & $\begin{array}{c}1.380^{* * *} \\
(0.288)\end{array}$ & \\
\hline Net Contributions per Loop & & & $\begin{array}{l}0.006^{* * *} \\
(0.001)\end{array}$ & & & $\begin{array}{l}0.647^{* * *} \\
(0.138)\end{array}$ \\
\hline UNE Ratio & $\begin{array}{l}0.050^{* * *} \\
(0.007)\end{array}$ & $\begin{array}{l}0.040^{* * *} \\
(0.009)\end{array}$ & $\begin{array}{l}0.055^{* * *} \\
(0.010)\end{array}$ & $\begin{array}{l}0.365^{* * *} \\
(0.086)\end{array}$ & $\begin{array}{l}0.384^{* * *} \\
(0.108)\end{array}$ & $\begin{array}{l}6.259^{* * *} \\
(1.724)\end{array}$ \\
\hline Alltel & & $\begin{array}{l}-0.651^{* *} \\
(0.312)\end{array}$ & $\begin{array}{l}-1.564^{* * *} \\
(0.357)\end{array}$ & & $\begin{array}{c}-11.111^{* * *} \\
(4.131)\end{array}$ & $\begin{array}{l}-226.756^{* * *} \\
(64.551)\end{array}$ \\
\hline BellSouth & & $\begin{array}{l}0.333^{* *} \\
(0.108)\end{array}$ & $\begin{array}{l}0.129 \\
(0.117)\end{array}$ & & $\begin{array}{l}2.336 \\
(1.437)\end{array}$ & $\begin{array}{l}-90.037^{* * *} \\
(24.537)\end{array}$ \\
\hline$S B C$ & & $\begin{array}{l}-0.186 \\
(0.117)\end{array}$ & $\begin{array}{l}-0.017 \\
(0.123)\end{array}$ & & $\begin{array}{l}0.527 \\
(1.608)\end{array}$ & $\begin{array}{l}-1.091 \\
(16.476)\end{array}$ \\
\hline Sprint & & $\begin{array}{c}0.337 \\
(0.316)\end{array}$ & $\begin{array}{l}-0.124 \\
(0.336)\end{array}$ & & $\begin{array}{l}-1.953 \\
(3.566)\end{array}$ & $\begin{array}{l}-52.843 \\
(37.674)\end{array}$ \\
\hline Qwest & & $\begin{array}{l}-0.084 \\
(0.101)\end{array}$ & $\begin{array}{l}0.229^{* *} \\
(0.113)\end{array}$ & & $\begin{array}{l}-1.109 \\
(1.246)\end{array}$ & $\begin{array}{l}48.956^{* * *} \\
(16.614)\end{array}$ \\
\hline Verizon & & $\begin{array}{l}-0.004 \\
(0.105)\end{array}$ & $\begin{array}{l}-0.115 \\
(0.114)\end{array}$ & & $\begin{array}{l}1.297 \\
(1.535)\end{array}$ & $\begin{array}{l}-87.951^{* * *} \\
(25.259)\end{array}$ \\
\hline Cellular Carriers & $\begin{array}{l}-0.007 \\
(0.009)\end{array}$ & $\begin{array}{l}-0.008 \\
(0.011)\end{array}$ & $\begin{array}{c}0.022^{* *} \\
(0.011)\end{array}$ & $\begin{array}{c}0.121 \\
(0.114)\end{array}$ & $\begin{array}{c}0.016 \\
(0.130)\end{array}$ & $\begin{array}{l}8.508^{* * *} \\
(2.154)\end{array}$ \\
\hline Annual Payroll & $\begin{array}{l}0.394^{* * *} \\
(0.044)\end{array}$ & $\begin{array}{l}0.393^{* * *} \\
(0.044)\end{array}$ & $\begin{array}{l}0.396^{* * * *} \\
(0.045)\end{array}$ & & & \\
\hline Population & & & & $\begin{array}{l}-3.560 \\
(2.860)\end{array}$ & $\begin{array}{l}-4.120 \\
(2.880)\end{array}$ & $\begin{array}{l}-0.002^{* * *} \\
(0.000)\end{array}$ \\
\hline Median Household Income & $\begin{array}{l}4.1 \mathrm{e}-05^{* * *} \\
(3.4 \mathrm{e}-06)\end{array}$ & $\begin{array}{l}4.24 \mathrm{e}-05^{* * *} \\
(3.45 \mathrm{e}-06)\end{array}$ & $\begin{array}{c}3.12 \mathrm{e}-05^{* * *} \\
(4.31 \mathrm{e}-06)\end{array}$ & & & \\
\hline Income & & & & $\begin{array}{l}-0.002 \\
(0.010)\end{array}$ & $\begin{array}{c}0.003^{* *} \\
(0.001)\end{array}$ & $\begin{array}{l}0.007^{* * *} \\
(0.002)\end{array}$ \\
\hline Median Age & $\begin{array}{l}-0.031^{* * *} \\
(0.007)\end{array}$ & $\begin{array}{c}-0.026^{* * *} \\
(0.007)\end{array}$ & $\begin{array}{l}-0.020^{* * *} \\
(0.007)\end{array}$ & $\begin{array}{l}-0.050 \\
(0.096)\end{array}$ & $\begin{array}{l}0.012 \\
(0.099)\end{array}$ & $\begin{array}{l}-1.207 \\
(1.039)\end{array}$ \\
\hline Assistance & $\begin{array}{l}0.030^{*} \\
(0.016)\end{array}$ & $\begin{array}{c}0.037^{*} \\
(0.016)\end{array}$ & $\begin{array}{c}0.047^{* * *} \\
(0.016)\end{array}$ & $\begin{array}{l}0.249 \\
(0.213)\end{array}$ & $\begin{array}{l}0.358 \\
(0.217)\end{array}$ & $\begin{array}{l}15.883^{* * *} \\
(4.021)\end{array}$ \\
\hline Entrant Flexible Regulation & $\begin{array}{l}-0.145^{* * *} \\
(0.049)\end{array}$ & $\begin{array}{l}-0.170^{* *} \\
(0.055)\end{array}$ & $\begin{array}{l}-0.273^{* * *} \\
(0.060)\end{array}$ & $\begin{array}{l}-0.493 \\
(0.652)\end{array}$ & $\begin{array}{l}-0.655 \\
(0.718)\end{array}$ & $\begin{array}{l}-9.869 \\
(7.687)\end{array}$ \\
\hline PSC Appointed & $\begin{array}{l}0.010^{* * *} \\
(0.055)\end{array}$ & $\begin{array}{l}0.137^{* *} \\
(0.066)\end{array}$ & $\begin{array}{c}0.116^{*} \\
(0.069)\end{array}$ & $\begin{array}{l}-0.709 \\
(0.717)\end{array}$ & $\begin{array}{c}-0.348 \\
(0.847)\end{array}$ & $\begin{array}{l}-27.751^{* *} \\
(10.541)\end{array}$ \\
\hline Muniban & $\begin{array}{l}-0.094 \\
(0.109)\end{array}$ & $\begin{array}{l}-0.004^{*} \\
(0.016)\end{array}$ & $\begin{array}{c}0.068 \\
(0.123)\end{array}$ & $\begin{array}{l}-0.840 \\
(1.167)\end{array}$ & $\begin{array}{l}0.367 \\
(1.239)\end{array}$ & $\begin{array}{l}31.578^{* *} \\
(14.263)\end{array}$ \\
\hline Number of Observations & 11,865 & 11,865 & 11,865 & 1,927 & 1,927 & 1,927 \\
\hline
\end{tabular}

Notes: Standard errors in parentheses. Significance of coefficients at the $10 \%, 5 \%$, and $1 \%$ levels are shown by $*$, $* *$, and $* * *$, respectively. 
Table 4. Estimates for net positive contributions only.

\begin{tabular}{lcc}
\hline \hline Regression Number & 1 & 2 \\
Dependent Variable: & Number of Entrants & $\begin{array}{c}\text { Number of Entrants } \\
\text { (Including Incumbents) }\end{array}$ \\
\hline
\end{tabular}

$\begin{array}{lll}\text { Net Positive Indicator (by County) } & 0.132^{* * *} & 0.107^{* *} \\ (12,033 \text { Observations) } & (0.057) & (0.053)\end{array}$

Net Positive Indicator (by Study Area) $1.932^{* *}$

(1,937 Observations) (0.817) (0.821)

Net Positive Indicator (by State) $\quad 28.276^{* * *} \quad 29.935^{* * *}$

(192 Observations) (10.067) (10.048)

Notes: Standard errors in parentheses. Significance of coefficients at the $10 \%, 5 \%$, and $1 \%$ levels are shown by *, $* *$, and ${ }^{* * *}$, respectively. 
Figure 1. Net contributions by local loop into the Universal Service Fund, by state, 2004

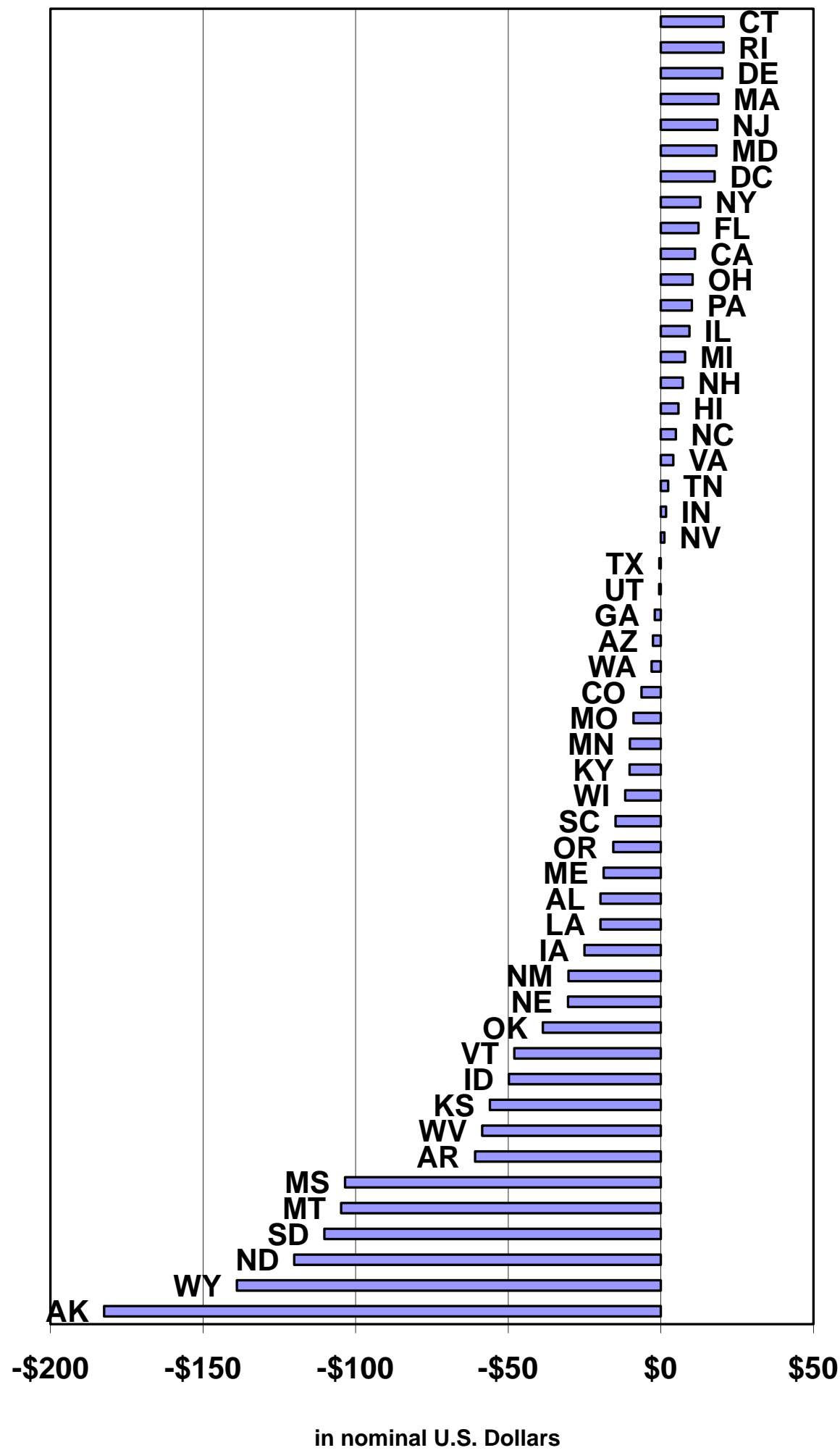

